\title{
Epigenetic Mechanisms Underlying Adult Post Stroke Neurogenesis
}

\author{
Xianshuang Liu ${ }^{1, *} \mathbb{C}$, Baoyan Fan ${ }^{1} \mathbb{C}$, Michael Chopp ${ }^{1,2}$ and Zhenggang Zhang ${ }^{1}$ \\ 1 Department of Neurology, Henry Ford Health System, Detroit, MI 48202, USA; bfan1@hfhs.org (B.F.); \\ mchopp1@hfhs.org (M.C.); zzhang1@hfhs.org (Z.Z.) \\ 2 Department of Physics, Oakland University, Rochester, MI 48309, USA \\ * Correspondence: xliu2@hfhs.org; Tel.: +1-313-916-5995
}

Received: 23 July 2020; Accepted: 25 August 2020; Published: 27 August 2020

check for updates

\begin{abstract}
Stroke remains the leading cause of adult disability. Post-stroke neurogenesis contributes to functional recovery. As an intrinsic neurorestorative process, it is important to elucidate the molecular mechanism underlying stroke-induced neurogenesis and to develop therapies designed specifically to augment neurogenesis. Epigenetic mechanisms include DNA methylation, histone modification and its mediation by microRNAs and long-non-coding RNAs. In this review, we highlight how epigenetic factors including DNA methylation, histone modification, microRNAs and long-non-coding RNAs mediate stroke-induced neurogenesis including neural stem cell self-renewal and cell fate determination. We also summarize therapies targeting these mechanisms in the treatment of stroke.
\end{abstract}

Keywords: stroke; epigenetics; microRNAs; histone deacetylation; adult neurogenesis; long non-coding RNA

\section{Introduction}

Stroke is one of the leading causes of morbidity and mortality in the U.S. and worldwide, which often leads to long-term neurological deficits and disability. Treatments of ischemic stroke with thrombolysis using tissue plasminogen activator (tPA) for the treatment of acute stroke patients within $4.5 \mathrm{~h}$ and mechanical endovascular thrombectomy for patients with acute ischemic stroke within $24 \mathrm{~h}$ due to a large artery occlusion results in only approximately one third of patients experiencing early brain reperfusion [1]. However, approximately two thirds of patients remain with neurologic impairment and disability. Therefore, post stroke rehabilitation becomes a major therapeutic focus for most stroke patients. Unfortunately, the currently available therapies are only rarely successful in improving recovery from neurological deficits. Neural stem cells are present in the adult brain of human and rodent [2-11]. Neurogenesis contributes to improvement of neurological function [3,7-23]. Although stroke induces stem cells to generate new neurons, post-stroke neurogenesis is modest and insufficient to restore neurological function [8-11,23]. It is therefore vital to identify the molecular and cellular signals required to promote neurogenesis after stroke.

Epigenetics is the study of heritable changes in gene function that cannot be attributed to DNA sequence variations. Epigenetic mechanisms can regulate different physiological processes that occur in a living organism, including cellular proliferation and differentiation. A deeper knowledge of the epigenetic modifications related to stroke and its risk factors could provide the basis for the development of innovative approaches in the prevention and treatment of this disabling disease. In the last decade, evidence has emerged supporting the involvement of epigenetic mechanisms in many neurodegenerative diseases and stroke [24-26]. In this review article, we describe the different types of epigenetic mechanisms and their involvement in the pathogenesis of stroke-induced neurogenesis. 


\section{Stroke-Induced Neurogenesis}

In the adult rodent brain, neurogenesis occurs throughout life in two discrete regions, primarily in the subventricular zone (SVZ) of the lateral ventricle and in the subgranular zone (SGZ) of the dentate gyrus (DG) [3,27-29]. Neurogenesis after stroke is present in peri-infarct regions and is essential for brain repair processes and cognitive restoration during stroke recovery [30-32]. We and others demonstrated that focal cerebral ischemia dramatically increases proliferation of SVZ progenitor cells in rodents and human $[3,13,14,17,23,33]$. Following proliferation, many SVZ neuroblasts abandon the rostral migratory system/olfactory complex [34] and migrate laterally toward the ischemic boundary zone [8-11,13,33,35-38]. Upon arrival, some SVZ neuroblasts integrate and differentiate, expressing markers of spiny neo-striatal projection neurons [3,21,23]. Increased neurogenesis in the dentate gyrus following stroke is also associated with impairment of hippocampus-dependent memory, although the extent to which stroke-induced neurogenesis contributes to the hippocampal cognitive function is controversial [39-43]. Ablation of newly generated neuroblasts in ischemic brain reduces spontaneous functional recovery and causes cognitive deficits in a mouse model of middle cerebral artery occlusion (MCAO) [20,42-44], indicating that stroke-induced neurogenesis impacts neurological outcomes. In addition, neurogenesis contributes to axonal remodeling, dendrite outgrowth $[21,45]$ and synapse connectivity [21,45]. It has also been shown that even re-establishment of a fraction of damaged neuronal circuits substantially improves neurological function [33]. Stroke-induced neurogenesis has also been demonstrated in the adult human brain, even in advanced age patients [7,14,46-48]. However, neurogenesis in response to stroke is insufficient to restore neurological function [33,49]. Elucidating molecular mechanisms underlying stroke-induced neurogenesis could lead to the development of new therapies to amplify endogenous neurogenesis, consequently leading to the improvement of neurological function during stroke recovery.

\section{Epigenetics in Adult Neurogenesis after Stroke}

\subsection{Overview of Epigenetics in the Gene Regulation}

Epigenetics is critical for normal development and cell growth and likely provides an important interface among genes, environment and disease. Epigenetic abnormalities have been found to be causative factors in numerous diseases [50]. Epigenetic mechanisms include histone covalent post-translational modifications, introduction of histone variants, chromatin remodeling, DNA methylation, imprinting and RNA interference [50]. We highlight these major epigenetic mechanisms in different stages of adult neurogenesis in the SVZ and SGZ/dentate gyrus after stroke.

\subsection{DNA Methylation and Demethylation}

DNA methylation involves the chemical covalent modification of the 5-carbon position of cytosine to produce 5-methylcytosine $(5 \mathrm{mC})$ on $\mathrm{CpG}$ islands, which renders the chromatin more tightly closed and inaccessible for the transcriptional machinery leading to silencing of gene expression. A family of DNA methyltransferases (Dnmts) is responsible for the catalysis of DNA methylation for preserving or generating $5 \mathrm{mCs}$ on the genome. In addition, methyl-CpG-binding domain (MBD) family members, such as MBD1 and MeCP2, can also bind methylated CpGs in the promoters and suppress gene expression [51]. Recent studies have revealed that knockdown of Dnmt1, Dnmt3a, MBD1 and MeCP2 significantly influence both proliferating NPCs and differentiated neurons by its direct epigenetic regulation of many neurogenic genes [52,53]. Moreover, previous research investigating epigenetic changes following MCAO in mice demonstrated upregulated global DNA methylation within the brain, and genetic or pharmacologic DNMT inhibition using 5-aza-dC, a MTase inhibitor decreased stroke severity [54,55], suggesting that DNA methyltransferase contributes to delayed ischemic brain injury.

In contrast with DNA methylation, a DNA demethylation mechanism has been recently discovered, which involves the removal of the methyl group by actively reversing the form $5 \mathrm{mC}$ to unmodified cytosine $(\mathrm{C})$ through the ten-eleven translocation (TET) proteins-mediated oxidation of $5 \mathrm{mC}$ to 
5-hydroxymethylcytosine (5hmC), 5-formylcytosine (5fC) and 5-carboxylcytosine (5caC), leading to transcriptional activation and gene expression [56]. Deletion of TET proteins markedly reduced the proliferation of adult NPCs by the increase of gene hypermethylation involved in adult NPC proliferation, for example galanin (Gal), chondroitin sulfate proteoglycan $4(\mathrm{Ng} 2)$ and neuroglobin $(\mathrm{Ngb})$, and reduced their expression in NPCs [57-60]. These data suggest that DNA methylation and demethylation precisely coordinate neurogenesis. However, understanding the role of dynamic DNA methylation on neurogenesis is still in its infancy. Whether methylation of gene expression plays an important role in the regulation of neurogenesis after stroke has not been investigated. Genome-wide maps of different cytosine modifications at single-base solution during the neural lineage commitment, from ESCs to NSCs to neurons, are clearly needed for future studies. In addition, given the complexity and heterogeneity of neurogenesis, the approaches of epigenomic and gene expression analyses at the single-cell level must be developed as well.

\subsection{Histone Acetylation and Deacetylation}

DNA associates with histone proteins in subunits called nucleosomes that form chromatin. Histones can undergo a number of acetylation and deacetylation modifications catalyzed by histone acetyltransferases (HATs) and histone deacetylases (HDACs), respectively, that can allow or prevent transcription in response to the cellular environment. HDACs are divided into four classes based on their homology and structure. Classes I, II and IV comprise Zn2 ${ }^{+}$-dependent HDACs, whereas Class III is made up of the NAD-dependent sirtuins. Numerous synthetic or natural product HDAC inhibitors (HDACi) have been developed for cancers and other neurodegenerative diseases [61,62]. Ischemia alters the expression of multiple HDAC proteins, and these have become popular targets for preclinical neuroprotection studies in stroke [63]. Recent studies have demonstrated protective effects of HDAC inhibition by anti-inflammation and inhibition of proapoptotic factors in acute treatment of focal cerebral ischemia model of rats (1-6 h after stroke) with various compounds including valproic acid, trichostatin A and sodium butyrate [64-73].

There is a significant body of evidence implying the proneurogenic actions of HATs and HDACs in regulating adult neurogenesis under physiological conditions [74]. For example, treatment with an HDAC inhibitor promoted neurite growth and neurogenesis in primary cortical cultures. The function of HDAC inhibitors during the late stage of stroke remains little known. Our previous study demonstrated that administration of Valproate acid (VPA) at a dose of $100 \mathrm{mg} / \mathrm{kg}$ starting $24 \mathrm{~h}$ after stroke increased acetylated histone $\mathrm{H} 4$ expression in neuroblasts and the number of new neurons in striatal ischemic boundary region, as well as increased oligodendrocytes, myelinated axons and neurogenesis in the peri-infarct region 28 days after stroke, which, in concert, were associated with improved neurological outcome [75]. In a rat model of MCAO, post-insult treatment with sodium butyrate (SB) or trichostatin A (TSA) robustly increased cell proliferation in the SVZ and DG of the ischemic brain, and SB also induced the migration of neural precursors to areas of injury by the regulation of BDNF-TrkB-dependent neurogenesis after ischemic injury $[64,76]$. These data suggest that modulation of histone acetylation in NPCs is involved in stroke-induced neurogenesis.

Despite the wide usage of HDAC inhibitors, however, the contribution of the individual HDACs to neurogenesis and other neurorestorative mechanisms after stroke remains largely unknown. The action of HDAC enzymes is complex, with some subtypes exhibiting protective effects while others promoting cell death. Furthermore, certain classes of HDAC enzymes are expressed outside of the nucleus where they influence the function of diverse proteins in a non-epigenetic manner. Further exploration of the roles of individual HDACs in regulating adult neurogenesis using conditional knockout mice of different HATs and HDACs will help to refine our understanding of the complex role of these proteins in regulating specific aspects of adult neurogenesis and their potential molecular mechanisms in contributing to stroke pathogenesis and subsequent recovery. 


\subsection{Polycomb Repressive Complex 2 (PRC2) Core Proteins}

The core of Polycomb Group protein 2 (PRC2) comprises Ezh2, Suz12, Eed and Jarid2 subunits, which inhibit gene expression by catalyzing histone modifications such as di- and trimethylation on histone H3 (H3K27me2 and H3K27me3) at the promoters of specific genes [77]. The function of PRC2 during development and adult neurogenesis has been studied. Yusuke et al. found that, during neocortical development, Ezh2 and Eed suppress the cortical neurogenesis and promote astrogenesis by repressing the promoter of the proneural gene neurogenin1 [78]. In adult neurogenesis, Zhang et al. reported that conditional knockout of Ezh2 in NSCs/progenitor cells reduces proliferation, leading to a decrease in the number of neurons in hippocampus and ultimately impairments in spatial learning and memory, contextual fear memory and pattern separation [79]. Our new data show that stroke significantly increased SUZ12 and EZH2 in NSCs derived from SVZ and SGZ, whereas histone active marker H3K4me3 exhibited a significant decrease. Using ChIRP-Western blot and RNA immnunoprecipitation (RIP) assay, chromatin proteins including SUZ12, EZH2 and H3K27me3 were observed to be physically associated with long non-coding RNA (lncRNA) H19, whose association was significantly higher in the ischemic NSCs compared with those from non-ischemic NSCs. Furthermore, our data demonstrate that knockdown of lncRNA markedly reduced levels of $\mathrm{EZH} 2$ and $\mathrm{H} 3 \mathrm{~K} 27 \mathrm{me} 3$ at the promoters of cell cycle-related genes, leading to the upregulation of p27 expression and consequently inhibition of NSC proliferation [80]. Our novel preliminary data suggest that stroke alters histone factors and thereby the recruitment of epigenetic states to target genes, which underlie stroke-induced neurogenesis.

\subsection{MiRNA and Stroke-Induced Neurogenesis}

MicroRNAs are 22-nucleotide noncoding RNAs that can downregulate gene products by translational repression when partially complementary sequences are present in the $3^{\prime}$-untranslated regions ( $3^{\prime}$-UTR) of the target mRNAs or by directing mRNA degradation. MiRNAs are expressed in a tissue-specific manner and are considered to play important roles in cell proliferation, apoptosis and differentiation [81].

Stroke alters the profiles of miRNAs in the brain and in blood samples obtained from humans and rodents [82-85]. NSCs express miRNAs and the functions of miRNAs in neurogenesis after stroke have been recently revealed [86-95] (Table 1). In a global screen study of mature miRNAs, we identified that miR-124a, a neuron-specific miRNA, was dramatically decreased in ischemic SVZ NPCs extracted from a rat MCAO model. Furthermore, we found the Jagged-1 and associated Notch signaling, well-known regulators of neurogenesis, are potential targets of miR-124 in NSCs [96]. In addition, we found that components of the miR-17-92 cluster were significantly upregulated in ischemic NPCs. Overexpression of the miR-17-92 cluster increases the proliferation and survival of NPCs by reducing target PTEN (phosphatase and tensin homolog), while Sonic hedgehog (Shh) pathway recruits N-MYC to regulate miR-17-92 cluster expression in NPCs [97]. Using a transgenic mouse line with conditional ablation of the miR-17-92 cluster in nestin lineage NSCs, ablation of the miR-17-92 cluster significantly reduced the number of proliferating NSCs and neuroblasts and neuronal differentiation in the dentate gyrus (DG) of the hippocampus and significantly impaired hippocampal-dependent learning and memory [98], suggesting a functional role of the miR-17-92 cluster in mediating stroke-induced neurogenesis and functional recovery by the SHH/MYC signaling pathway.

Table 1. MiRNAs and the regulation of neurogenesis after stroke.

\begin{tabular}{cccc}
\hline miRNAs & Target Genes/Regulated Pathways & Function & Citation \\
\hline miR-124a & JAG1-Notch pathway & $\begin{array}{c}\text { Reduce NPC proliferation and promote } \\
\text { neuronal differentiation. }\end{array}$ \\
\hline miR-17-92 & PTEN, Enigma homolog 1 (ENH1) & Increase NPC proliferation and inhibit cell death. & [97] \\
\hline miR-146a & IRAK1 & Increase NPC proliferation and inhibit NPC death. & [99] \\
\hline
\end{tabular}


Table 1. Cont.

\begin{tabular}{|c|c|c|c|}
\hline miRNAs & Target Genes/Regulated Pathways & Function & Citation \\
\hline $\operatorname{miR}-126$ & PTPN/AKT-ERK pathway & $\begin{array}{c}\text { Promote neurogenesis and improved } \\
\text { neurobehavioral outcomes. }\end{array}$ & [100] \\
\hline $\operatorname{miR}-195$ & $\begin{array}{l}\text { Sema3A/Cdc42/JNK, Sema3A, } \\
\text { NF-kB pathway }\end{array}$ & $\begin{array}{c}\text { Anti-apoptosis, anti-inflammation, neurovascular } \\
\text { Protection and promoting NSC proliferation } \\
\text { and migration. }\end{array}$ & {$[101]$} \\
\hline miR-9 & HDAC4 & Promote neuroprotective and regenerative efficacy. & {$[102]$} \\
\hline $\operatorname{miR}-210$ & $\begin{array}{l}\text { BDNF, COX10, ISCU/AMPK pathway, } \\
\text { SOCS1-STAT3-VEGF-C Pathway }\end{array}$ & $\begin{array}{l}\text { Affect proliferation, differentiation, apoptosis, } \\
\text { mitochondrial function of NSCs, } \\
\text { neurovacularization. }\end{array}$ & {$[103-105]$} \\
\hline $\operatorname{miR}-365$ & Pax6 & Inhibit neurogenesis. & {$[106]$} \\
\hline $\operatorname{miR}-148 b$ & wnt $/ \beta$-catenin signaling & Attenuate proliferation and differentiation of NSCs. & [107] \\
\hline $\operatorname{miR}-128-3 p$ & Nrf2 & $\begin{array}{l}\text { Inhibit NSC proliferation and enhancement of } \\
\text { oxidative stress. }\end{array}$ & {$[108]$} \\
\hline miR-140-5p & IL1rap, IL1rapl1, VEGF and MEGF10 & Inhibit neurogenesis and capillary density. & [109] \\
\hline $\operatorname{miR}-27 b$ & AMPK & Inhibit neurogenesis. & [110] \\
\hline
\end{tabular}

Moreover, using a more comprehensive Ago2-based RNA immunoprecipitation to immunoprecipate Ago2-RNA complexes followed by RNA sequencing (Ago2 RIP-seq) approach, we profiled the miRNomes in NPCs from ischemic rats and found that stroke substantially changed Ago2-associated miRNA profiles in NPCs compared to those in non-ischemic NPCs. We also discovered a new complex repertoire of isomiRs and multiple miRNA-miRNA* pairs and numerous novel miRNAs in the non-ischemic and ischemic NPCs [111]. miR-146a, which was known to regulate immune response, was the most upregulated miRNA in ischemic NPCs. However, the function of miR-146a in the NSCs has not been reported. Our data show that overexpression of miR-146a in NPCs significantly increased their differentiation into $\mathrm{O}^{+}$OPCs, which was further confirmed in primary OPCs, showing gain-of-function of miR-146a in primary OPCs increased expression of myelin proteins, whereas attenuation of endogenous miR-146a suppressed generation of myelin proteins by targeting IRAK1 expression. Attenuation of IRAK1 in OPCs substantially increased myelin proteins and decreased OPC apoptosis [99].

In addition, other groups identified several other miRNAs that can impact adult neurogenesis after stroke. For instance, miR-210, a known hypoxia-related miRNA, was found to promote the neurogenesis and long-term outcomes by targeting brain derived neurotrophic factor (BDNF) after focal ischemia in mice [103]. Intriguingly, another study revealed that miR-210 influences proliferation and Doublecortin (DCX) positive neuroblast apoptosis by glycolytic activity and increases mitochondrial potential via targeting cytochrome $c$ assembly protein (COX10) and iron-sulfur cluster scaffold homolog (ISCU) in mice subjected to MCAO [112]. Inhibition of miR-148b enhances proliferation and differentiation of NSCs via Wnt/ $\beta$-Catenin Signaling in an ischemic mouse stroke model, which contributes to functional recovery after stroke [107]. Knockdown of miR-365 enhances PAX6-mediated neurogenesis from astrocytes and attenuates neuronal injury in the brain after ischemic stroke [106]. AAV-mediated overexpression of miR-140-5p decreased the levels of IL1rap, IL1rapl1, VEGF and MEGF10 in the ischemic mouse hippocampus and inhibited neurogenesis, indicating a novel early warning biomarker for late-onset post-stroke depression $[109,113]$. Injection of miRNA-27b inhibitors enhances neurogenesis of SVZ and hippocampus, behavioral function recovery and spatial memory via AMPK activation in a mouse ischemic stroke model [110]. MiRNA-126 promoted neurogenesis in ischemic mouse brain by directly inhibiting its target PTPN9 and activating AKT and ERK signaling pathways, and it further improved neurobehavioral outcomes [114]. Collectively, these data suggest that miRNAs play critical roles in stroke-induced neurogenesis and neurological outcomes post stroke. 


\subsection{Long Non-Coding RNAs and Neurogenesis}

Long non-coding RNAs (lncRNAs), non-protein coding transcripts longer than 200 nucleotides, have been suggested to play important roles in the regulation of tissue homeostasis and pathophysiological conditions [115]. LncRNAs regulate gene expression at the levels of chromatin structure, transcription control, RNA processing and translation [115]. Many aberrant lncRNA expressions such as MEG3, H19, MALAT1, ZFAS1, GAS5, LincRNA-EPS, SHNG16, etc. were suggested to regulate cell apoptosis, angiogenesis, inflammation and cell death in different brain cell types after stroke [116-122]. NSCs express IncRNAs and the functions of lncRNAs in the self-renewal and differentiation of stem cells are beginning to be appreciated [123-125]. In our recent study, we performed a comprehensive lncRNA profile analysis from adult NSCs in the SVZ of adult non-ischemic and ischemic rats subjected to seven-day MCAO. In total, 409 mRNAs were identified to be significantly upregulated and 255 were downregulated in ischemic NSCs compared with non-ischemic NSCs. Our study for the first time revealed differential lncRNA profiles and lncRNA-mRNA co-expression network in the NSCs that are associated with stroke-induced neurogenesis [80]. Furthermore, we demonstrated that the top upregulated lncRNA H19 mediates the proliferation and neuronal differentiation of NSCs by recruiting chromatin remodeling proteins and by regulating miR-675 expression to modulate neurogenesis-related transcription. H19 inactivation in NSCs significantly attenuates motor and cognitive function after stroke in vivo. In addition, we identified multiple lncRNAs that correlated with their adjacent genes such as Stat1 and GFAP, which are known regulators of NSCs [80]. However, mechanistic modulation of these lncRNAs in stroke-induced neurogenesis and neurological outcomes remains to be determined. Unveiling their mechanism will provide new insights into the epigenetic control of brain remodeling after cerebral ischemia.

\subsection{Exosomal RNAs as Novel Regulators of the Adult Neurogenic Niche after Stroke}

\subsubsection{Crosstalk between NSCs and Other Cell Types}

Exosomes are endosomal origin membranous nanovesicles with a size of $\sim 30-150 \mathrm{~nm}$ in diameter and are released by all living cells [126]. Exosomes mediate intercellular communication including neuron-glia and neuron-endothelial cells in the brain, by transferring proteins, lipids and genomic materials including miRNAs between source and target cells [126].

Adult neurogenesis is tightly controlled by the neurogenic niche, which provides a structural and molecular cue for NSC proliferation and the differentiation and functional integration of new neurons. We and other groups demonstrated that NSCs form close associations with peri-infarct blood vessels in a region of active vascular remodeling, in which angiogenesis is causally linked to post-stroke neurogenesis [127,128]. Angiogenic factors including vascular endothelial growth factor (VEGF) and angiopoietin 2 were reported to regulate the coupling of angiogenesis and neurogenesis [129-131]. In addition to NPCs, neuroblasts and blood vessels, the neurogenic niche includes astrocytes, microglia, ependymal cells, immune cells, etc. [132-134]. Interestingly, as noted above, multiple miRNAs abundant in the NSCs are also expressed in the neighboring cells, such as miR-146a and miR-124, which are co-expressed in NSCs and microglia $[96,99]$. However, the detailed molecular mechanism underlying their coupling after stroke remains unclear. Further investigation of the function of exosomes and RNA cargos in the communication of NSCs and adjacent cells after stroke may provide new therapeutic targets.

\subsubsection{Exosomal RNAs as a Potential Therapy in the Stroke}

Compared to cell therapy, exosome administration has advantages, such as the virtually zero probability for developing a tumor or malignant transformation. Neural stem cells-derived exosomes via their RNA cargoes hold great potential to promote brain repair and functional recovery for stroke and other neurological injuries. Our group uncovered that treatment of stroke with mesenchymal stem cells (MSCs)-derived exosomes alone or tailored MSC-derived exosomes enriched with the miR17-92 
cluster markedly increases neural plasticity and functional recovery after stroke via targeting PTEN to activate the $\mathrm{PI} 3 \mathrm{~K} /$ protein kinase B/mechanistic target of rapamycin/glycogen synthase kinase $3 \beta$ signaling pathway in rats [135]. In line with our study, Yang et al. reported that systemic administration of rabies virus glycoprotein (RVG) modified MSC-exosomes fused to exosomal protein lysosome-associated membrane glycoprotein $2 b$ (Lamp2b) and loaded with miR-124 protects against ischemic injury by inducing robust cortical neurogenesis [136]. In addition, exosomes from human urine-derived stem cells have been shown to enhance neurogenesis via the miR-26a/HDAC6 axis using an in vitro oxygen-glucose deprivation/reoxygenation (OGD/R) and an in vivo rat MCAO model [137]. MiR-124-loaded nanoparticles increase survival and neuronal differentiation of NSCs in vitro [138]. Exosomal lncRNAs also play an important role in the intercellular communication [139]. However, the mechanisms by which lncRNAs in exosome-mediated NSC communicate with other cells after stroke remain to be determined.

\section{Conclusions and Future Perspective}

Epigenetic mechanisms have established roles in adult neurogenesis within the normal brain. These roles have been demonstrated via studies of neurodevelopment, learning and memory. In comparison, the role of such mechanisms in neuroplasticity following injury has not been clearly defined. Epigenetic changes have been investigated following stroke, but mostly in the context of injury evolution. In this brief overview, we seek to capture the emerging excitement from the increase of a new understanding of epigenetic molecular mechanisms and their relevance to NSC function and dysfunction (Figure 1). These roles need to be examined independently in the context of the injured brain to provide a comprehensive understanding of how repair processes contribute to late recovery and to identify plausible candidates important for the induction of stroke-induced plasticity. We consider this review to be a snapshot of where things stand at this point in time, with emerging new epigenetic mechanisms and targets. Further investigation of DNA methylation and demethylation, histone modifications and non-coding RNA regulation following stroke will provide important insights into the basic mechanisms of such plasticity and further enhance our understanding of the brain's inherent regenerative capacity.

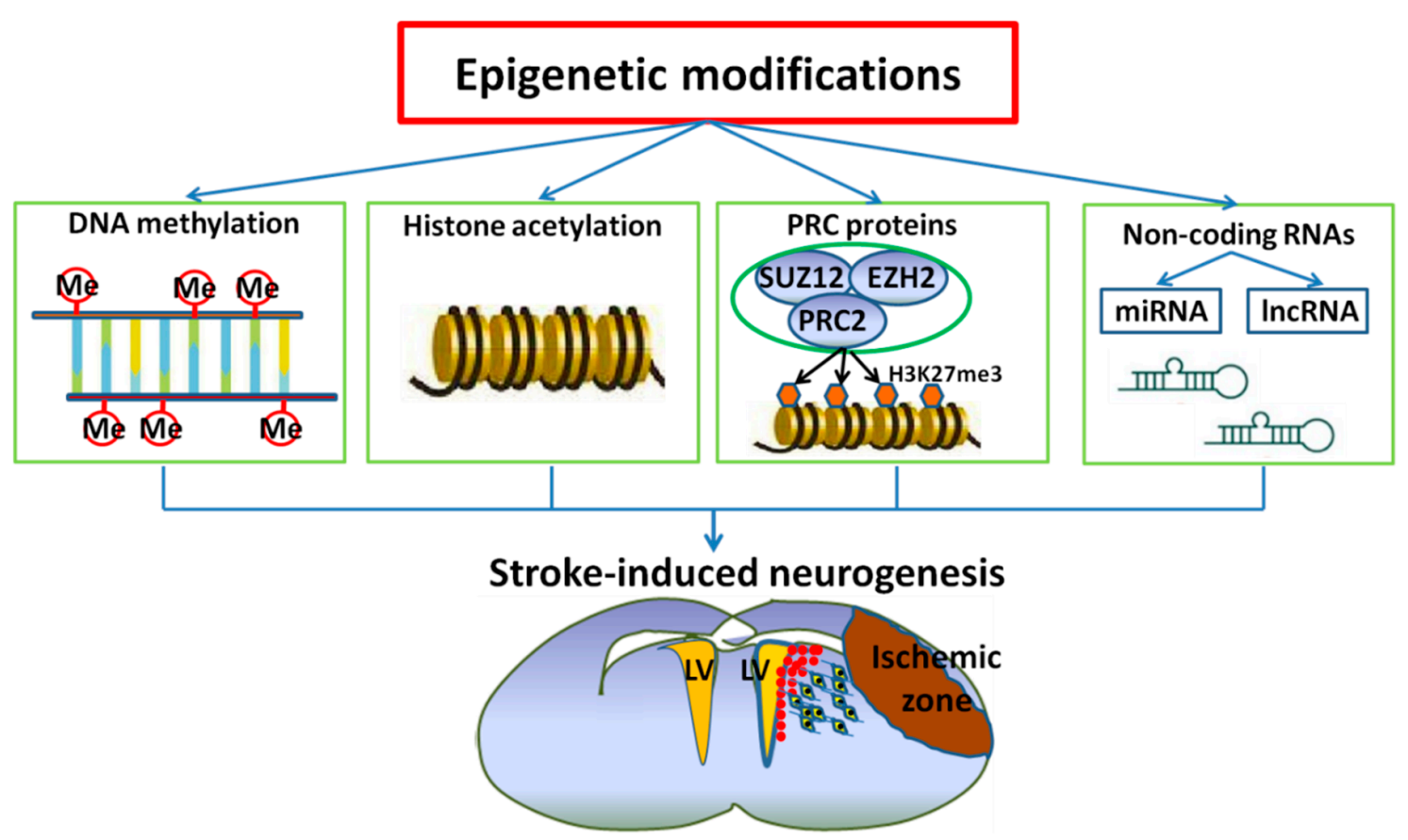

Figure 1. Proposed mechanistic models of the role of epigenetic changes including DNA methylation, histone acetylation, PCR core proteins, non-coding miRNAs and lncRNAs in the regulation of adult neurogenesis following stroke. 
Author Contributions: X.L., Z.Z., B.F. and M.C. contributed to writing the review. All authors have read and agreed to the published version of the manuscript.

Funding: This work was supported by the National Institutes of Health National Institute of Diabetes and Digestive and Kidney Disease grant \# RO1 RDK102861A (X.L), American Heart Association Grant-in-Aid \# 14GRNT20460167 (X.L), RO1 NS075156 (Z.Z) and RO1 NS088656 (M.C.).

Conflicts of Interest: The authors declare no conflict of interest.

\section{References}

1. Tawil, S.E.; Muir, K.W. Thrombolysis and thrombectomy for acute ischaemic stroke. Clin. Med. 2017, 17, 161-165. [CrossRef]

2. Abrous, D.N.; Koehl, M.; Le Moal, M. Adult neurogenesis: From precursors to network and physiology. Physiol. Rev. 2005, 85, 523-569. [CrossRef] [PubMed]

3. Alvarez-Buylla, A.; Herrera, D.G.; Wichterle, H. The subventricular zone: Source of neuronal precursors for brain repair. Prog. Brain Res. 2000, 127, 1-11.

4. Bellenchi, G.C.; Volpicelli, F.; Piscopo, V.; Perrone-Capano, C.; di Porzio, U. Adult neural stem cells: An endogenous tool to repair brain injury? J. Neurochem. 2013, 124, 159-167. [CrossRef] [PubMed]

5. Goncalves, J.T.; Schafer, S.T.; Gage, F.H. Adult neurogenesis in the Hippocampus: From stem cells to behavior. Cell 2016, 167, 897-914. [CrossRef] [PubMed]

6. Ming, G.L.; Song, H. Adult neurogenesis in the mammalian brain: Significant answers and significant questions. Neuron 2011, 70, 687-702. [CrossRef] [PubMed]

7. Minger, S.L.; Ekonomou, A.; Carta, E.M.; Chinoy, A.; Perry, R.H.; Ballard, C.G. Endogenous neurogenesis in the human brain following cerebral infarction. Regen. Med. 2007, 2, 69-74. [CrossRef]

8. Zhang, R.; Zhang, Z.; Wang, L.; Wang, Y.; Gousev, A.; Zhang, L.; Ho, K.L.; Morshead, C.; Chopp, M. Activated neural stem cells contribute to stroke-induced neurogenesis and neuroblast migration toward the infarct boundary in adult rats. J. Cereb. Blood Flow Metab. 2004, 24, 441-448. [CrossRef]

9. Zhang, R.; Zhang, Z.; Zhang, C.; Zhang, L.; Robin, A.; Wang, Y.; Lu, M.; Chopp, M. Stroke transiently increases subventricular zone cell division from asymmetric to symmetric and increases neuronal differentiation in the adult rat. J. Neurosci. 2004, 24, 5810-5815. [CrossRef]

10. Zhang, R.L.; Zhang, L.; Zhang, Z.G.; Morris, D.; Jiang, Q.; Wang, L.; Zhang, L.J.; Chopp, M. Migration and differentiation of adult rat subventricular zone progenitor cells transplanted into the adult rat striatum. Neuroscience 2003, 116, 373-382. [CrossRef]

11. Zhang, R.L.; Zhang, Z.G.; Chopp, M. Neurogenesis in the adult ischemic brain: Generation, migration, survival, and restorative therapy. Neuroscientist 2005, 11, 408-416. [CrossRef] [PubMed]

12. Jin, K.; Minami, M.; Lan, J.Q.; Mao, X.O.; Batteur, S.; Simon, R.P.; Greenberg, D.A. Neurogenesis in dentate subgranular zone and rostral subventricular zone after focal cerebral ischemia in the rat. Proc. Natl. Acad. Sci. USA 2001, 98, 4710-4715. [CrossRef] [PubMed]

13. Parent, J.M.; Vexler, Z.S.; Gong, C.; Derugin, N.; Ferriero, D.M. Rat forebrain neurogenesis and striatal neuron replacement after focal stroke. Ann. Neurol. 2002, 52, 802-813. [CrossRef] [PubMed]

14. Jin, K.; Wang, X.; Xie, L.; Mao, X.O.; Zhu, W.; Wang, Y.; Shen, J.; Mao, Y.; Banwait, S.; Greenberg, D.A. Evidence for stroke-induced neurogenesis in the human brain. Proc. Natl. Acad. Sci. USA 2006, 103, 13198-13202. [CrossRef]

15. Luskin, M.B. Restricted proliferation and migration of postnatally generated neurons derived from the forebrain subventricular zone. Neuron 1993, 11, 173-189. [CrossRef]

16. Zhang, R.L.; Chopp, M.; Roberts, C.; Jia, L.; Wei, M.; Lu, M.; Wang, X.; Pourabdollah, S.; Zhang, Z.G. Ascl1 lineage cells contribute to ischemia-induced neurogenesis and oligodendrogenesis. J. Cereb. Blood Flow Metab. 2011, 31, 614-625. [CrossRef]

17. Darsalia, V.; Heldmann, U.; Lindvall, O.; Kokaia, Z. Stroke-induced neurogenesis in aged brain. Stroke 2005, 36, 1790-1795. [CrossRef]

18. Jin, K.; Sun, Y.; Xie, L.; Peel, A.; Mao, X.O.; Batteur, S.; Greenberg, D.A. Directed migration of neuronal precursors into the ischemic cerebral cortex and striatum. Mol. Cell Neurosci. 2003, 24, 171-189. [CrossRef]

19. Parent, J.M. Injury-induced neurogenesis in the adult mammalian brain. Neuroscientist 2003, 9, $261-272$. [CrossRef] 
20. Jin, K.; Wang, X.; Xie, L.; Mao, X.O.; Greenberg, D.A. Transgenic ablation of doublecortin-expressing cells suppresses adult neurogenesis and worsens stroke outcome in mice. Proc. Natl. Acad. Sci. USA 2010, 107, 7993-7998. [CrossRef]

21. Yamashita, T.; Ninomiya, M.; Hernandez Acosta, P.; Garcia-Verdugo, J.M.; Sunabori, T.; Sakaguchi, M.; Adachi, K.; Kojima, T.; Hirota, Y.; Kawase, T.; et al. Subventricular zone-derived neuroblasts migrate and differentiate into mature neurons in the post-stroke adult striatum. J. Neurosci. 2006, 26, 6627-6636. [CrossRef] [PubMed]

22. Kim, E.J.; Ables, J.L.; Dickel, L.K.; Eisch, A.J.; Johnson, J.E. Ascl1 (Mash1) defines cells with long-term neurogenic potential in subgranular and subventricular zones in adult mouse brain. PLoS ONE 2011, 6, e18472. [CrossRef] [PubMed]

23. Zhang, R.L.; Zhang, Z.G.; Zhang, L.; Chopp, M. Proliferation and differentiation of progenitor cells in the cortex and the subventricular zone in the adult rat after focal cerebral ischemia. Neuroscience 2001, 105, 33-41. [CrossRef]

24. Qureshi, I.A.; Mehler, M.F. Emerging role of epigenetics in stroke: Part 1: DNA methylation and chromatin modifications. Arch. Neurol. 2010, 67, 1316-1322. [CrossRef] [PubMed]

25. Hu, Z.; Zhong, B.; Tan, J.; Chen, C.; Lei, Q.; Zeng, L. The emerging role of epigenetics in cerebral ischemia. Mol. Neurobiol. 2017, 54, 1887-1905. [CrossRef]

26. Felling, R.J.; Song, H. Epigenetic mechanisms of neuroplasticity and the implications for stroke recovery. Exp. Neurol. 2015, 268, 37-45. [CrossRef]

27. Gage, F.H.; Ray, J.; Fisher, L.J. Isolation, characterization, and use of stem cells from the CNS. Annu. Rev. Neurosci. 1995, 18, 159-192. [CrossRef]

28. Kirschenbaum, B.; Doetsch, F.; Lois, C.; Alvarez-Buylla, A. Adult subventricular zone neuronal precursors continue to proliferate and migrate in the absence of the olfactory bulb. J. Neurosci. 1999, 19, 2171-2180. [CrossRef]

29. Luskin, M.B.; Zigova, T.; Soteres, B.J.; Stewart, R.R. Neuronal progenitor cells derived from the anterior subventricular zone of the neonatal rat forebrain continue to proliferate in vitro and express a neuronal phenotype. Mol. Cell Neurosci. 1997, 8, 351-366. [CrossRef]

30. Xiong, Y.; Mahmood, A.; Chopp, M. Angiogenesis, neurogenesis and brain recovery of function following injury. Curr. Opin. Investig. Drugs 2010, 11, 298-308.

31. Noetel, A.; Elfimova, N.; Altmuller, J.; Becker, C.; Becker, D.; Lahr, W.; Nurnberg, P.; Wasmuth, H.; Teufel, A.; Buttner, R.; et al. Next generation sequencing of the Ago2 interacting transcriptome identified chemokine family members as novel targets of neuronal microRNAs in hepatic stellate cells. J. Hepatol. 2013, 58, 335-341. [CrossRef] [PubMed]

32. Chu, C.; Zhang, Q.C.; da Rocha, S.T.; Flynn, R.A.; Bharadwaj, M.; Calabrese, J.M.; Magnuson, T.; Heard, E.; Chang, H.Y. Systematic discovery of Xist RNA binding proteins. Cell 2015, 161, 404-416. [CrossRef] [PubMed]

33. Arvidsson, A.; Collin, T.; Kirik, D.; Kokaia, Z.; Lindvall, O. Neuronal replacement from endogenous precursors in the adult brain after stroke. Nat. Med. 2002, 8, 963-970. [CrossRef]

34. Kronenberg, G.; Wang, L.P.; Synowitz, M.; Gertz, K.; Katchanov, J.; Glass, R.; Harms, C.; Kempermann, G.; Kettenmann, H.; Endres, M. Nestin-expressing cells divide and adopt a complex electrophysiologic phenotype after transient brain ischemia. J. Cereb. Blood Flow Metab. 2005, 25, 1613-1624. [CrossRef]

35. Wang, L.; Zhang, Z.; Wang, Y.; Zhang, R.; Chopp, M. Treatment of stroke with erythropoietin enhances neurogenesis and angiogenesis and improves neurological function in rats. Stroke 2004, 35, 1732-1737. [CrossRef]

36. Liu, X.S.; Zhang, Z.G.; Zhang, L.; Morris, D.C.; Kapke, A.; Lu, M.; Chopp, M. Atorvastatin downregulates tissue plasminogen activator-aggravated genes mediating coagulation and vascular permeability in single cerebral endothelial cells captured by laser microdissection. J. Cereb. Blood Flow Metab. 2006, 26, 787-796. [CrossRef]

37. Zhang, R.; Wang, Y.; Zhang, L.; Zhang, Z.; Tsang, W.; Lu, M.; Zhang, L.; Chopp, M. Sildenafil (Viagra) induces neurogenesis and promotes functional recovery after stroke in rats. Stroke 2002, 33, 2675-2680. [CrossRef]

38. Zhang, R.; Zhang, L.; Zhang, Z.; Wang, Y.; Lu, M.; Lapointe, M.; Chopp, M. A nitric oxide donor induces neurogenesis and reduces functional deficits after stroke in rats. Ann. Neurol. 2001, 50, 602-611. [CrossRef] 
39. Cuartero, M.I.; de la Parra, J.; Pérez-Ruiz, A.; Bravo-Ferrer, I.; Durán-Laforet, V.; García-Culebras, A.; García-Segura, J.M.; Dhaliwal, J.; Frankland, P.W.; Lizasoain, I.; et al. Abolition of aberrant neurogenesis ameliorates cognitive impairment after stroke in mice. J. Clin. Investig. 2019, 129, 1536-1550. [CrossRef]

40. Woitke, F.; Ceanga, M.; Rudolph, M.; Niv, F.; Witte, O.W.; Redecker, C.; Kunze, A.; Keiner, S. Adult hippocampal neurogenesis poststroke: More new granule cells but aberrant morphology and impaired spatial memory. PLoS ONE 2017, 12, e0183463. [CrossRef]

41. Kathner-Schaffert, C.; Karapetow, L.; Günther, M.; Rudolph, M.; Dahab, M.; Baum, E.; Lehmann, T.; Witte, O.W.; Redecker, C.; Schmeer, C.W.; et al. Early stroke induces long-term impairment of adult neurogenesis accompanied by hippocampal-mediated cognitive decline. Cells 2019, 8, 1654. [CrossRef] [PubMed]

42. Iwai, M.; Stetler, R.A.; Xing, J.; Hu, X.; Gao, Y.; Zhang, W.; Chen, J.; Cao, G. Enhanced oligodendrogenesis and recovery of neurological function by erythropoietin after neonatal hypoxic/ischemic brain injury. Stroke 2010, 41, 1032-1037. [CrossRef] [PubMed]

43. Sun, F.; Wang, X.; Mao, X.; Xie, L.; Jin, K. Ablation of neurogenesis attenuates recovery of motor function after focal cerebral ischemia in middle-aged mice. PLoS ONE 2012, 7, e46326. [CrossRef] [PubMed]

44. Chen, C.; Wang, Y.; Yang, G.Y. Stem cell-mediated gene delivering for the treatment of cerebral ischemia: Progress and prospectives. Curr. Drug Targets 2013, 14, 81-89. [CrossRef] [PubMed]

45. Cao, H.; Yang, C.S.; Rana, T.M. Evolutionary emergence of microRNAs in human embryonic stem cells. PLoS ONE 2008, 3, e2820. [CrossRef]

46. Macas, J.; Nern, C.; Plate, K.H.; Momma, S. Increased generation of neuronal progenitors after ischemic injury in the aged adult human forebrain. J. Neurosci. 2006, 26, 13114-13119. [CrossRef]

47. Lichtenwalner, R.J.; Parent, J.M. Adult neurogenesis and the ischemic forebrain. J. Cereb. Blood Flow Metab. 2006, 26, 1-20. [CrossRef]

48. Kempermann, G.; Gage, F.H.; Aigner, L.; Song, H.; Curtis, M.A.; Thuret, S.; Kuhn, H.G.; Jessberger, S.; Frankland, P.W.; Cameron, H.A.; et al. Human adult neurogenesis: Evidence and remaining questions. Cell Stem Cell 2018, 23, 25-30. [CrossRef]

49. Zhang, L.; Chopp, M.; Zhang, R.L.; Wang, L.; Zhang, J.; Wang, Y.; Toh, Y.; Santra, M.; Lu, M.; Zhang, Z.G. Erythropoietin amplifies stroke-induced oligodendrogenesis in the rat. PLoS ONE 2010, 5, e11016. [CrossRef]

50. Zoghbi, H.Y.; Beaudet, A.L. Epigenetics and human disease. Cold Spring Harb. Perspect. Biol. 2016, 8, a019497. [CrossRef]

51. Greenberg, M.V.C.; Bourc'his, D. The diverse roles of DNA methylation in mammalian development and disease. Nat. Rev. Mol. Cell Biol. 2019, 20, 590-607. [CrossRef] [PubMed]

52. Jobe, E.M.; Zhao, X. DNA methylation and adult neurogenesis. Brain Plast. 2017, 3, 5-26. [CrossRef] [PubMed]

53. Zhao, X.; Ueba, T.; Christie, B.R.; Barkho, B.; McConnell, M.J.; Nakashima, K.; Lein, E.S.; Eadie, B.D.; Willhoite, A.R.; Muotri, A.R.; et al. Mice lacking methyl-CpG binding protein 1 have deficits in adult neurogenesis and hippocampal function. Proc. Natl. Acad. Sci. USA 2003, 100, 6777-6782. [CrossRef] [PubMed]

54. Choi, I.A.; Lee, C.S.; Kim, H.Y.; Choi, D.H.; Lee, J. Effect of inhibition of DNA methylation combined with task-specific training on chronic stroke recovery. Int. J. Mol. Sci. 2018, 19, 2019. [CrossRef] [PubMed]

55. Endres, M.; Meisel, A.; Biniszkiewicz, D.; Namura, S.; Prass, K.; Ruscher, K.; Lipski, A.; Jaenisch, R.; Moskowitz, M.A.; Dirnagl, U. DNA methyltransferase contributes to delayed ischemic brain injury. J. Neurosci. 2000, 20, 3175-3181. [CrossRef]

56. Wu, X.; Zhang, Y. TET-mediated active DNA demethylation: Mechanism, function and beyond. Nat. Rev. Genet. 2017, 18, 517-534. [CrossRef]

57. Etchegaray, J.P.; Chavez, L.; Huang, Y.; Ross, K.N.; Choi, J.; Martinez-Pastor, B.; Walsh, R.M.; Sommer, C.A.; Lienhard, M.; Gladden, A.; et al. The histone deacetylase SIRT6 controls embryonic stem cell fate via TET-mediated production of 5-hydroxymethylcytosine. Nat. Cell Biol. 2015, 17, 545-557. [CrossRef]

58. Montalbán-Loro, R.; Lozano-Ureña, A.; Ito, M.; Krueger, C.; Reik, W.; Ferguson-Smith, A.C.; Ferrón, S.R. TET3 prevents terminal differentiation of adult NSCs by a non-catalytic action at Snrpn. Nat. Commun. 2019, 10, 1726. [CrossRef]

59. Santiago, M.; Antunes, C.; Guedes, M.; Sousa, N.; Marques, C.J. TET enzymes and DNA hydroxymethylation in neural development and function-how critical are they? Genomics 2014, 104, 334-340. [CrossRef] 
60. Verma, N.; Pan, H.; Doré, L.C.; Shukla, A.; Li, Q.V.; Pelham-Webb, B.; Teijeiro, V.; González, F.; Krivtsov, A.; Chang, C.J.; et al. TET proteins safeguard bivalent promoters from de novo methylation in human embryonic stem cells. Nat. Genet. 2018, 50, 83-95. [CrossRef]

61. Li, Y.; Seto, E. HDACs and HDAC Inhibitors in Cancer Development and Therapy. Cold Spring Harb. Perspect. Med. 2016, 6, a026831. [CrossRef] [PubMed]

62. Didonna, A.; Opal, P. The promise and perils of HDAC inhibitors in neurodegeneration. Ann. Clin. Transl. Neurol. 2015, 2, 79-101. [CrossRef] [PubMed]

63. Langley, B.; Brochier, C.; Rivieccio, M.A. Targeting histone deacetylases as a multifaceted approach to treat the diverse outcomes of stroke. Stroke 2009, 40, 2899-2905. [CrossRef] [PubMed]

64. Kim, H.J.; Rowe, M.; Ren, M.; Hong, J.S.; Chen, P.S.; Chuang, D.M. Histone deacetylase inhibitors exhibit anti-inflammatory and neuroprotective effects in a rat permanent ischemic model of stroke: Multiple mechanisms of action. J. Pharmacol. Exp. Ther. 2007, 321, 892-901. [CrossRef] [PubMed]

65. Brookes, R.L.; Crichton, S.; Wolfe, C.D.A.; Yi, Q.; Li, L.; Hankey, G.J.; Rothwell, P.M.; Markus, H.S. Sodium valproate, a histone deacetylase inhibitor, is associated with reduced stroke risk after previous ischemic stroke or transient ischemic attack. Stroke 2018, 49, 54-61. [CrossRef] [PubMed]

66. Demyanenko, S.V.; Nikul, V.V.; Uzdensky, A.B. The neuroprotective effect of the HDAC2/3 inhibitor MI192 on the Penumbra after photothrombotic stroke in the mouse brain. Mol. Neurobiol. 2020, 57, 239-248. [CrossRef]

67. Formisano, L.; Laudati, G.; Guida, N.; Mascolo, L.; Serani, A.; Cuomo, O.; Cantile, M.; Boscia, F.; Molinaro, P.; Anzilotti, S.; et al. HDAC4 and HDAC5 form a complex with DREAM that epigenetically down-regulates NCX3 gene and its pharmacological inhibition reduces neuronal stroke damage. J. Cereb. Blood Flow Metab. 2019, 271678X19884742. [CrossRef]

68. Kannangara, T.S.; Vani, M.A. Delayed treatment with histone deacetylase inhibitors promotes stroke recovery. J. Neurosci. 2017, 37, 12088-12090. [CrossRef]

69. Li, S.; Lu, X.; Shao, Q.; Chen, Z.; Huang, Q.; Jiao, Z.; Huang, X.; Yue, M.; Peng, J.; Zhou, X.; et al. Early histone deacetylase inhibition mitigates ischemia/reperfusion brain injury by reducing microglia activation and modulating their phenotype. Front. Neurol. 2019, 10, 893. [CrossRef]

70. Park, M.J.; Sohrabji, F. The histone deacetylase inhibitor, sodium butyrate, exhibits neuroprotective effects for ischemic stroke in middle-aged female rats. J. Neuroinflamm. 2016, 13, 300. [CrossRef]

71. Patnala, R.; Arumugam, T.V.; Gupta, N.; Dheen, S.T. HDAC inhibitor Sodium butyrate-mediated epigenetic regulation enhances neuroprotective function of microglia during ischemic stroke. Mol. Neurobiol. 2017, 54, 6391-6411. [CrossRef] [PubMed]

72. Zhao, H.; Li, G.; Zhang, S.; Li, F.; Wang, R.; Tao, Z.; Ma, Q.; Han, Z.; Yan, F.; Fan, J.; et al. Inhibition of histone deacetylase 3 by MiR-494 alleviates neuronal loss and improves neurological recovery in experimental stroke. J. Cereb. Blood Flow Metab. 2019, 39, 2392-2405. [CrossRef] [PubMed]

73. Ziemka-Nalecz, M.; Jaworska, J.; Sypecka, J.; Polowy, R.; Filipkowski, R.K.; Zalewska, T. Sodium butyrate, a histone deacetylase inhibitor, exhibits neuroprotective/neurogenic effects in a rat model of neonatal Hypoxia-Ischemia. Mol. Neurobiol. 2017, 54, 5300-5318. [CrossRef] [PubMed]

74. Sun, G.; Fu, C.; Shen, C.; Shi, Y. Histone deacetylases in neural stem cells and induced pluripotent stem cells. J. Biomed. Biotechnol. 2011, 2011, 835968. [CrossRef] [PubMed]

75. Liu, X.S.; Chopp, M.; Kassis, H.; Jia, L.F.; Hozeska-Solgot, A.; Zhang, R.L.; Chen, C.; Cui, Y.S.; Zhang, Z.G. Valproic acid increases white matter repair and neurogenesis after stroke. Neuroscience 2012, 220, 313-321. [CrossRef]

76. Jaworska, J.; Zalewska, T.; Sypecka, J.; Ziemka-Nalecz, M. Effect of the HDAC inhibitor, Sodium butyrate, on neurogenesis in a rat model of neonatal Hypoxia-Ischemia: Potential mechanism of action. Mol. Neurobiol. 2019, 56, 6341-6370. [CrossRef]

77. Margueron, R.; Reinberg, D. The Polycomb complex PRC2 and its mark in life. Nature 2011, 469, 343-349. [CrossRef]

78. Pereira, J.D.; Sansom, S.N.; Smith, J.; Dobenecker, M.W.; Tarakhovsky, A.; Livesey, F.J. Ezh2, the histone methyltransferase of PRC2, regulates the balance between self-renewal and differentiation in the cerebral cortex. Proc. Natl. Acad. Sci. USA 2010, 107, 15957-15962. [CrossRef]

79. Zhang, J.; Ji, F.; Liu, Y.; Lei, X.; Li, H.; Ji, G.; Yuan, Z.; Jiao, J. Ezh2 regulates adult hippocampal neurogenesis and memory. J. Neurosci. 2014, 34, 5184-5199. [CrossRef] 
80. Fan, B.; Pan, W.; Wang, X.; Wei, M.; He, A.; Zhao, A.; Chopp, M.; Zhang, Z.G.; Liu, X.S. Long noncoding RNA mediates stroke-induced neurogenesis. Stem Cells 2020. [CrossRef]

81. Bartel, D.P. MicroRNAs: Genomics, biogenesis, mechanism, and function. Cell 2004, 116, 281-297. [CrossRef]

82. Dharap, A.; Bowen, K.; Place, R.; Li, L.C.; Vemuganti, R. Transient focal ischemia induces extensive temporal changes in rat cerebral microRNAome. J. Cereb. Blood Flow Metab. 2009, 29, 675-687. [CrossRef]

83. Jeyaseelan, K.; Lim, K.Y.; Armugam, A. MicroRNA expression in the blood and brain of rats subjected to transient focal ischemia by middle cerebral artery occlusion. Stroke 2008, 39, 959-966. [CrossRef] [PubMed]

84. Liu, D.Z.; Tian, Y.; Ander, B.P.; Xu, H.; Stamova, B.S.; Zhan, X.; Turner, R.J.; Jickling, G.; Sharp, F.R. Brain and blood microRNA expression profiling of ischemic stroke, intracerebral hemorrhage, and kainate seizures. J. Cereb. Blood Flow Metab. 2010, 30, 92-101. [CrossRef] [PubMed]

85. Tan, K.S.; Armugam, A.; Sepramaniam, S.; Lim, K.Y.; Setyowati, K.D.; Wang, C.W.; Jeyaseelan, K. Expression profile of MicroRNAs in young stroke patients. PLoS ONE 2009, 4, e7689. [CrossRef] [PubMed]

86. Barca-Mayo, O.; Lu, Q.R. Fine-tuning oligodendrocyte development by microRNAs. Front. Neurosci. 2012, 6, 13. [CrossRef]

87. Dugas, J.C.; Notterpek, L. MicroRNAs in oligodendrocyte and Schwann cell differentiation. Dev. Neurosci. 2011, 33, 14-20. [CrossRef]

88. Emery, B. Regulation of oligodendrocyte differentiation and myelination. Science 2010, 330, 779-782. [CrossRef]

89. Junker, A.; Hohlfeld, R.; Meinl, E. The emerging role of microRNAs in multiple sclerosis. Nat. Rev. Neurol. 2011, 7, 56-59. [CrossRef]

90. Liu, J.; Casaccia, P. Epigenetic regulation of oligodendrocyte identity. Trends Neurosci. 2010, 33, $193-201$. [CrossRef]

91. Kawahara, H.; Imai, T.; Okano, H. MicroRNAs in Neural Stem Cells and Neurogenesis. Front. Neurosci. 2012, 6, 30. [CrossRef] [PubMed]

92. Lang, M.F.; Shi, Y. Dynamic roles of microRNAs in neurogenesis. Front. Neurosci. 2012, 6, 71. [CrossRef] [PubMed]

93. Li, X.; Jin, P. Roles of small regulatory RNAs in determining neuronal identity. Nat. Rev. Neurosci. 2010, 11, 329-338. [CrossRef] [PubMed]

94. Liu, C.; Zhao, X. MicroRNAs in adult and embryonic neurogenesis. Neuromol. Med. 2009, 11, 141-152. [CrossRef] [PubMed]

95. Akao, Y.; Iio, A.; Itoh, T.; Noguchi, S.; Itoh, Y.; Ohtsuki, Y.; Naoe, T. Microvesicle-mediated RNA molecule delivery system using monocytes/macrophages. Mol. Ther. 2011, 19, 395-399. [CrossRef]

96. Liu, X.S.; Chopp, M.; Zhang, R.L.; Tao, T.; Wang, X.L.; Kassis, H.; Hozeska-Solgot, A.; Zhang, L.; Chen, C.; Zhang, Z.G. MicroRNA profiling in subventricular zone after stroke: MiR-124a regulates proliferation of neural progenitor cells through Notch signaling pathway. PLoS ONE 2011, 6, e23461. [CrossRef]

97. Liu, X.S.; Chopp, M.; Wang, X.L.; Zhang, L.; Hozeska-Solgot, A.; Tang, T.; Kassis, H.; Zhang, R.L.; Chen, C.; $\mathrm{Xu}$, J.; et al. MicroRNA-17-92 cluster mediates the proliferation and survival of neural progenitor cells after stroke. J. Biol. Chem. 2013, 288, 12478-12488. [CrossRef]

98. Pan, W.L.; Chopp, M.; Fan, B.; Zhang, R.; Wang, X.; Hu, J.; Zhang, X.M.; Zhang, Z.G.; Liu, X.S. Ablation of the microRNA-17-92 cluster in neural stem cells diminishes adult hippocampal neurogenesis and cognitive function. FASEB J. 2019, 33, 5257-5267. [CrossRef]

99. Liu, X.S.; Chopp, M.; Pan, W.L.; Wang, X.L.; Fan, B.Y.; Zhang, Y.; Kassis, H.; Zhang, R.L.; Zhang, X.M.; Zhang, Z.G. MicroRNA-146a promotes oligodendrogenesis in stroke. Mol. Neurobiol. 2017, 54, 227-237. [CrossRef]

100. Geng, W.; Tang, H.; Luo, S.; Lv, Y.; Liang, D.; Kang, X.; Hong, W. Exosomes from miRNA-126-modified ADSCs promotes functional recovery after stroke in rats by improving neurogenesis and suppressing microglia activation. Am. J. Transl. Res. 2019, 11, 780-792.

101. Cheng, H.Y.; Wang, Y.S.; Hsu, P.Y.; Chen, C.Y.; Liao, Y.C.; Juo, S.H. Mir-195 has a potential to treat ischemic and hemorrhagic stroke through neurovascular protection and neurogenesis. Mol. Ther. Methods Clin. Dev. 2019, 13, 121-132. [CrossRef] [PubMed]

102. Nampoothiri, S.S.; Rajanikant, G.K. Mir-9 upregulation integrates post-ischemic neuronal survival and regeneration in vitro. Cell. Mol. Neurobiol. 2019, 39, 223-240. [CrossRef] [PubMed] 
103. Zeng, L.L.; He, X.S.; Liu, J.R.; Zheng, C.B.; Wang, Y.T.; Yang, G.Y. Lentivirus-mediated overexpression of MicroRNA-210 improves long-term outcomes after focal cerebral ischemia in mice. CNS Neurosci. Ther. 2016, 22, 961-969. [CrossRef] [PubMed]

104. Zeng, L.; He, X.; Wang, Y.; Tang, Y.; Zheng, C.; Cai, H.; Liu, J.; Wang, Y.; Fu, Y.; Yang, G.Y. MicroRNA-210 overexpression induces angiogenesis and neurogenesis in the normal adult mouse brain. Gene Ther. 2014, 21, 37-43. [CrossRef]

105. Meng, Z.Y.; Kang, H.L.; Duan, W.; Zheng, J.; Li, Q.N.; Zhou, Z.J. MicroRNA-210 Promotes accumulation of neural precursor cells around ischemic foci after cerebral ischemia by regulating the SOCS1-STAT3-VEGF-C Pathway. J. Am. Heart Assoc. 2018, 7, e005052. [CrossRef]

106. Mo, J.L.; Liu, Q.; Kou, Z.W.; Wu, K.W.; Yang, P.; Chen, X.H.; Sun, F.Y. MicroRNA-365 modulates astrocyte conversion into neuron in adult rat brain after stroke by targeting Pax6. Glia 2018, 66, 1346-1362. [CrossRef]

107. Wang, J.; Chen, T.; Shan, G. Mir-148b regulates proliferation and differentiation of neural stem cells via wnt/ $\beta$-catenin signaling in rat ischemic stroke model. Front. Cell. Neurosci. 2017, 11, 329. [CrossRef]

108. Li, R.; Li, X.; Wu, H.; Yang, Z.; Fei, L.; Zhu, J. Theaflavin attenuates cerebral ischemia/reperfusion injury by abolishing miRNA-128-3p-mediated Nrf2 inhibition and reducing oxidative stress. Mol. Med. Rep. 2019, 20, 4893-4904. [CrossRef]

109. Liang, H.B.; He, J.R.; Tu, X.Q.; Ding, K.Q.; Yang, G.Y.; Zhang, Y.; Zeng, L.L. MicroRNA-140-5p: A novel circulating biomarker for early warning of late-onset post-stroke depression. J. Psychiatr. Res. 2019, 115, 129-141. [CrossRef]

110. Wang, Z.; Yuan, Y.; Zhang, Z.; Ding, K. Inhibition of miRNA-27b enhances neurogenesis via AMPK activation in a mouse ischemic stroke model. FEBS Open Bio 2019, 9, 859-869. [CrossRef]

111. Liu, X.S.; Fan, B.Y.; Pan, W.L.; Li, C.; Levin, A.M.; Wang, X.; Zhang, R.L.; Zervos, T.M.; Hu, J.; Zhang, X.M.; et al. Identification of miRNomes associated with adult neurogenesis after stroke using Argonaute 2-based RNA sequencing. RNA Biol. 2017, 14, 488-499. [CrossRef] [PubMed]

112. Chen, Z.; Li, Y.; Zhang, H.; Huang, P.; Luthra, R. Hypoxia-regulated microRNA-210 modulates mitochondrial function and decreases ISCU and COX10 expression. Oncogene 2010, 29, 4362-4368. [CrossRef] [PubMed]

113. Sun, J.; Tao, S.; Liu, L.; Guo, D.; Xia, Z.; Huang, M. Mir-140-5p regulates angiogenesis following ischemic stroke by targeting VEGFA. Mol. Med. Rep. 2016, 13, 4499-4505. [CrossRef] [PubMed]

114. Qu, M.; Pan, J.; Wang, L.; Zhou, P.; Song, Y.; Wang, S.; Jiang, L.; Geng, J.; Zhang, Z.; Wang, Y.; et al. MicroRNA-126 regulates angiogenesis and neurogenesis in a mouse model of focal cerebral ischemia. Mol. Ther. Nucleic Acids 2019, 16, 15-25. [CrossRef] [PubMed]

115. Batista, P.J.; Chang, H.Y. Long noncoding RNAs: Cellular address codes in development and disease. Cell 2013, 152, 1298-1307. [CrossRef] [PubMed]

116. Akella, A.; Bhattarai, S.; Dharap, A. Long noncoding RNAs in the pathophysiology of ischemic stroke. Neuromol. Med. 2019, 21, 474-483. [CrossRef]

117. Bao, M.H.; Szeto, V.; Yang, B.B.; Zhu, S.Z.; Sun, H.S.; Feng, Z.P. Long non-coding RNAs in ischemic stroke. Cell Death Dis. 2018, 9, 281. [CrossRef]

118. Chen, R.; Xu, X.; Huang, L.; Zhong, W.; Cui, L. The regulatory role of long noncoding RNAs in different brain cell types involved in ischemic stroke. Front. Mol. Neurosci. 2019, 12, 61. [CrossRef]

119. Kaur, H.; Sarmah, D.; Saraf, J.; Vats, K.; Kalia, K.; Borah, A.; Yavagal, D.R.; Dave, K.R.; Ghosh, Z.; Bhattacharya, P. Noncoding RNAs in ischemic stroke: Time to translate. Ann. N. Y. Acad. Sci. 2018, 1421, 19-36. [CrossRef]

120. Ren, W.; Yang, X. Pathophysiology of long non-coding RNAs in ischemic stroke. Front. Mol. Neurosci. 2018, 11, 96. [CrossRef]

121. Wang, Q.; Liu, X.; Zhu, R. Long noncoding RNAs as diagnostic and therapeutic targets for ischemic stroke. Curr. Pharm. Des. 2019, 25, 1115-1121. [CrossRef] [PubMed]

122. Wang, Y.; Pan, W.Y.; Ge, J.S.; Wang, X.D.; Chen, W.; Luo, X.; Wang, Y.L. A review of the relationship between long noncoding RNA and post-stroke injury repair. J. Int. Med. Res. 2019, 47, 4619-4624. [CrossRef] [PubMed]

123. Antoniou, D.; Stergiopoulos, A.; Politis, P.K. Recent advances in the involvement of long non-coding RNAs in neural stem cell biology and brain pathophysiology. Front. Physiol. 2014, 5, 155. [CrossRef] [PubMed]

124. Iyengar, B.R.; Choudhary, A.; Sarangdhar, M.A.; Venkatesh, K.V.; Gadgil, C.J.; Pillai, B. Non-coding RNA interact to regulate neuronal development and function. Front. Cell. Neurosci. 2014, 8, 47. [CrossRef] 
125. Wang, L.; Liu, Y.; Sun, S.; Lu, M.; Xia, Y. Regulation of neuronal-glial fate specification by long non-coding RNAs. Rev. Neurosci. 2016, 27, 491-499. [CrossRef]

126. Théry, C.; Zitvogel, L.; Amigorena, S. Exosomes: Composition, biogenesis and function. Nat. Rev. Immunol. 2002, 2, 569-579. [CrossRef]

127. Teng, H.; Zhang, Z.G.; Wang, L.; Zhang, R.L.; Zhang, L.; Morris, D.; Gregg, S.R.; Wu, Z.; Jiang, A.; Lu, M.; et al. Coupling of angiogenesis and neurogenesis in cultured endothelial cells and neural progenitor cells after stroke. J. Cereb. Blood Flow Metab. 2008, 28, 764-771. [CrossRef]

128. Zhang, R.L.; Chopp, M.; Roberts, C.; Liu, X.; Wei, M.; Nejad-Davarani, S.P.; Wang, X.; Zhang, Z.G. Stroke increases neural stem cells and angiogenesis in the neurogenic niche of the adult mouse. PLOS ONE 2014, 9, e113972. [CrossRef]

129. Tata, M.; Ruhrberg, C. Cross-talk between blood vessels and neural progenitors in the developing brain. Neuronal Signal. 2018, 2, NS20170139. [CrossRef]

130. Hansen, T.M.; Moss, A.J.; Brindle, N.P. Vascular endothelial growth factor and angiopoietins in neurovascular regeneration and protection following stroke. Curr. Neurovasc. Res. 2008, 5, 236-245. [CrossRef]

131. Liu, X.S.; Chopp, M.; Zhang, R.L.; Hozeska-Solgot, A.; Gregg, S.C.; Buller, B.; Lu, M.; Zhang, Z.G. Angiopoietin 2 mediates the differentiation and migration of neural progenitor cells in the subventricular zone after stroke. J. Biol. Chem. 2009, 284, 22680-22689. [CrossRef] [PubMed]

132. Wang, F.W.; Hao, H.B.; Zhao, S.D.; Zhang, Y.M.; Liu, Q.; Liu, H.J.; Liu, S.M.; Yuan, Q.H.; Bing, L.J.; Ling, E.A.; et al. Roles of activated astrocyte in neural stem cell proliferation and differentiation. Stem Cell Res. 2011, 7, 41-53. [CrossRef] [PubMed]

133. Hou, B.R.; Jiang, C.; Wang, Z.N.; Ren, H.J. Exosome-mediated crosstalk between microglia and neural stem cells in the repair of brain injury. Neural Regen. Res. 2020, 15, 1023-1024. [CrossRef] [PubMed]

134. Kokaia, Z.; Martino, G.; Schwartz, M.; Lindvall, O. Cross-talk between neural stem cells and immune cells: The key to better brain repair? Nat. Neurosci. 2012, 15, 1078-1087. [CrossRef] [PubMed]

135. Xin, H.; Katakowski, M.; Wang, F.; Qian, J.Y.; Liu, X.S.; Ali, M.M.; Buller, B.; Zhang, Z.G.; Chopp, M. MicroRNA cluster miR-17-92 cluster in exosomes enhance neuroplasticity and functional recovery after stroke in rats. Stroke 2017, 48,747-753. [CrossRef]

136. Yang, J.; Zhang, X.; Chen, X.; Wang, L.; Yang, G. Exosome mediated delivery of miR-124 promotes neurogenesis after ischemia. Mol. Ther. Nucleic Acids 2017, 7, 278-287. [CrossRef]

137. Ling, X.; Zhang, G.; Xia, Y.; Zhu, Q.; Zhang, J.; Li, Q.; Niu, X.; Hu, G.; Yang, Y.; Wang, Y.; et al. Exosomes from human urine-derived stem cells enhanced neurogenesis via miR-26a/HDAC6 axis after ischaemic stroke. J. Cell. Mol. Med. 2020, 24, 640-654. [CrossRef]

138. Saraiva, C.; Talhada, D.; Rai, A.; Ferreira, R.; Ferreira, L.; Bernardino, L.; Ruscher, K. MicroRNA-124-loaded nanoparticles increase survival and neuronal differentiation of neural stem cells in vitro but do not contribute to stroke outcome in vivo. PLoS ONE 2018, 13, e0193609. [CrossRef]

139. Dragomir, M.; Chen, B.; Calin, G.A. Exosomal lncRNAs as new players in cell-to-cell communication. Transl. Cancer Res. 2018, 7 (Suppl. 2), S243-S252. [CrossRef]

(C) 2020 by the authors. Licensee MDPI, Basel, Switzerland. This article is an open access article distributed under the terms and conditions of the Creative Commons Attribution (CC BY) license (http://creativecommons.org/licenses/by/4.0/). 